\title{
A Monetary Constitution for Europe?
}

\section{Antonio Martino}

The most savage controversies are those about matters as to which there is no good evidence either way.

-Bertrand Russell

The discussions on European monetary unification appear to confirm the wisdom of Bertrand Russell's insight. Both supporters and opponents of the idea are forced to resort to essentially theoretical arguments, as there is no specific empirical evidence on the merits of the various alternatives. In what follows, after looking at some advantages of a common currency for Europe and at the objections that are being raised against it, I will say something about the transition process as currently envisaged.

The argument of this paper is that a common European currency may be desirable or undesirable (feasible or unfeasible) depending on the kind of monetary constitution (or lack of it) that is adopted. ${ }^{1}$ On the one hand, a monetary rule appears to be a necessary precondition for moving toward a common European currency. If, on the other hand, money continues to be used as an instrument of discretionary policy, monetary unification is unlikely to be achieved. Agreement on the need for a monetary rule is far more important than the choice of the actual monetary constitution. Therefore, little will be said about the type of rule to adopt. ${ }^{2}$

Cato Journal, Vol. 10, No. 2 (Fall 1990). Copyright (c) Cato Institute. All rights reserved.

The author is Professor of Economics at the University of Rome, where he holds the Chair in Monetary History and Policy. He is also a Professor of Economics at the Free University Law School (LUISS) in Rome.

'By monetary constitution I mean a regime "in which the discretion of the policymaking authorities is constrained, at least in the short run" (Leijonhufvud 1987, p. 130).

${ }^{2}$ As J. M. Buchanan (1987, p. 124) pointed out, agreement on the need for a monetary constitution should take precedence over a determination of the specific kind of rule to be adopted. 


\section{Advantages of a Common Currency}

Monetary union in Europe is capable of being good, bad or indifferent. All depends on precisely how it is done.

-The Economist (1989)

Would Europe benefit from a common currency? ${ }^{3}$ If, for the moment, we ignore both the difficulties of achieving a common currency and the preoccupations with the conduct of monetary policy after its establishment, the answer is positive: Europe and the world would probably benefit a great deal.

Interestingly enough, most commentators seem convinced that the only advantage of a common currency for Europe would be the reduction of uncertainty in foreign exchange markets. ${ }^{4}$ For example, the governor of the Bank of England (Leigh-Pemberton 1989, p. 12) recently stated:

The benefits [of a single currency] are fairly easy to identify. Where prices within an area are quoted in a common currency, uncertainties arising from unpredictable exchange rate fluctuations within the area are removed. In consequence, business decisions are not complicated by a need to take account of possible exchange rate changes within the currency area, which would help to improve confidence, particularly in relation to investment decisions with long time horizons. Furthermore, there would no longer be any transactions costs associated with exchanging one currency for another or with trying to hedge against changes in rates.

I do not wish to deny the importance of reduced uncertainty in foreign exchange markets and of a saving in transactions costs, but it is reductive to see no other advantage in a common currency for Europe. As I shall try to show, there are other, possibly more relevant advantages. $I$ also believe that it is this reductive interpretation of the benefits of a common currency that has led to the fallacious identification of monetary unification with fixed exchange rates, which is responsible for some of the absurdities in the various political proposals. Let me list some of the main advantages other than the reduction in transactions costs.

A common European currency could provide an alternative to the U.S. dollar as an instrument of international liquidity. The "national" currency of such a large market could achieve the same degree of

${ }^{3}$ What follows draws on my 1989 paper and, to a lesser extent, on previous work. See Martino (1971a, 1971b, 1976, 1977, 1978a, 1978b, 1986, 1988).

${ }^{4}$ Apparently, this has been the consensus among professional economists and public opinion. See, for example, Vaubel (1979, p. 19) and The Economist (1989, p. 20). 
acceptability presently enjoyed by the dollar. The competition between the two major international currencies would result in a kind of "Gresham's law" in reverse, because the more stable currency would be preferred in international transactions. The overall stability of the international monetary system would increase. ${ }^{5}$

Europe would benefit in that it would be able to use its own currency, rather than the U.S. dollar, as a reserve asset. ${ }^{6}$ Needless to say, this would not be a minor advantage and might be at least as important as the saving in transactions costs. The United States would also benefit to the extent that a monetary system based on two currencies would make the external value of the dollar less volatile.

Inside Europe, a common currency would eliminate problems with the balance of payments, making the "adjustment process" smooth and automatic. There would be no balance-of-payments problems between, say, England and France because both countries would be using the same currency. National economic policies, therefore, would be relieved of one of their present worries. Finally, scarce resources presently dissipated in the collection, analysis, and discussion of intra-European balance-of-payments statistics could be diverted to more productive uses.

With a common European currency, provincial considerations would play no role in monetary decisions, which would aim at overall stability rather than respond to "local" pressures. As a result, for example, there would be only one rate of inflation, not twelve. This is a very important consideration. I know of no economist who is willing to argue that a proliferation of regional currencies in a given country would increase overall monetary stability on a national level. ${ }^{7}$

A common currency would make the liberalization of capital movements within Europe automatic and irreversible, with all of the

${ }^{5}$ For the analysis of currency competition, see, for example, Hayek (1976), Vaubel (1986), and Dowd (1988).

${ }^{6}$ If Europe had a common currency, there would be one central bank rather than twelve. This might result in a considerable saving if the European central bank would cost less than the present twelve national central banks (this is not clear, however, considering the lavish way eurocrats tend to treat themselves). Even more important, the dollar reserves presently used by the national central banks would become unnecessary and, if the common currency were allowed to float freely in international markets, the European central bank's reserve requirement would be very small.

${ }^{7} \mathrm{It}$ is in the light of this argument that one should read The Economist's (1989, p. 20) point: "Simply ask whether America would be better off with separate currencies for each of its states." Strangely enough, the only problem that the authoritative publication sees in having the United States use 50 different currencies is the cost of converting one into another. 


\section{Cato Journal}

known advantages in terms of personal liberty and economic efficiency. It would be as difficult to restrict capital movements in a region that uses the same currency as it is in a given country.

These are not all of the benefits to be gained from a common currency for Europe, but they are possibly more important than the advantage of reduced uncertainty in foreign exchanges and of savings in transactions costs. Furthermore, although the smoothness of the adjustment process and the elimination of balance-of-payments problems could also be achieved by a system of freely floating exchange rates among European national currencies, all the other advantages can be attained only by a single currency for Europe. ${ }^{8}$

\section{Objections to a Common Currency}

Several objections have been raised to adopting a single European currency. While some of these objections are undoubtedly well founded (if not insurmountable), others are definitely dubious. The most common objection is that "money does not manage itself"; that is, discretionary monetary management requires political control. Europe's present political institutions are inadequate for that kind of task. A variation on this theme is that the surrender of monetary sovereignty is unjustifiable at this point, since existing European political institutions could not guarantee member states that a common currency would be managed in a way in which they would approve.

Another objection is that a common currency would be premature, given the present heterogeneity of European national economies. Monetary unification, according to this view, should follow, not precede, "economic integration" (whatever that means).

A third objection holds that monetary unification would benefit "high-inflation countries" and harm "low-inflation countries." The idea is that with a common European currency inflation in Europe would settle at an average of existing national inflation rates.

Finally, there is a problem that is seldom explicitly stated: Money creation is an important source of revenue for national governments, and they are not ready to give it up easily.

${ }^{8}$ If these potential advantages are taken into consideration, then the evaluation of the performance of the European Monetary System becomes less favorable. Even granted that the "European Monetary System has not failed," because "the potential for an inflationary bias predicted by many economists has not materialized" and "has achieved lower exchange rate variability" (Fratianni 1988, p. 489), it is also true that none of the advantages of a common currency mentioned above has been achieved. Thus, Fratianni's conclusion that it is not clear whether the EMS has been a success is probably too benign. 


\section{Are the Objections Valid?}

None of these objections is insurmountable, and some are totally false. For example, different regions of the same national economy are often heterogeneous, yet this does not prevent them from using the same currency. Furthermore, no one has advocated separate regional currencies as an instrument to reduce national heterogeneity.

A different version of this argument draws on Keynesianism: A monetary union would prevent "individual member countries from each attaining their optimum combination of inflation and unemployment on the so-called Phillips curve" (Vaubel 1979, p. 20). As Vaubel pointed out, however, the "trade-off between inflation and unemployment has disappeared," and few economists believe that much good can result from monetary instability. From this point of view, therefore, Vaubel's $(1979$, p. 20) conclusion seems to be as valid today as it was in 1979: "If national monetary policy can no longer be used to raise employment, the economic cost of joining a monetary union must be small indeed."

In addition, there is no reason to suppose that a common currency would result in an inflation rate that would equal the average of today's national rates. If Europe adopted a common currency, it would have one rate of inflation (rather than twelve), which would be "high" or "low" depending on whether the rate of growth of the money supply at the European level was "high" or "low." Classifying countries as having "high inflation" or "low inflation" is highly misleading, because it suggests that somehow the degree of monetary stability or instability of a country is determined by some "inevitable law of historical destiny" and that it has nothing to do with the country's actual monetary policy. Monetary history provides irrefutable evidence that this is not the case.

It seems to me that there are only two valid objections to a common European currency. The first is related to the use of money as an instrument of discretionary policy, and the second is connected with its use as a source of revenue by European national governments. Before discussing these, however, I shall make a few remarks on the transition process and the Delors Report.

\section{The Delors Report}

It may very well be that European monetary union would be a great achievement, but that the road by which we are trying to reach it is conducive to serious breakdowns and accidents and, indeed, does not lead to its ultimate destination. What must worry all advocates of 


\section{Cato Journal}

European integration is precisely that the choice of an unworkable strategy will-again, and this time fatally-discredit the whole idea of a united Western Europe.

-Roland Vaubel (1979, p. 19)

Vaubel was right. Even today, much of the discredit surrounding the idea of a common European currency is due to the clumsy political attempts at planning a strategy for the transition. This is as true of the earlier efforts as it is of the latest of these ill-conceived political attempts: the Delors Report. Patrick Minford (1989, p. 28) has judged the report to be "a monstrous conspiracy of centralism, mounted by an $a d$ hoc alliance of central bankers and bureaucrats whose interests wonderfully coincide in this assault on consumer choice and democratic rights." These are strong words. But there is no doubt that the report lends itself to public choice analysis (Vaubel 1989) and that it offers no small amount of entertainment to those of us who are inclined to question the superior wisdom of bureaucrats and politicians.

It is true, as Minford (1989) has stressed, that the Delors Report marks a departure from the liberal philosophy of the European ideal (as most recently reconfirmed by the Single Act) and that it embraces a "statist" approach to European money."

The statist bias is probably a consequence of the report's original sin: identifying monetary unification with fixed exchange rates. ${ }^{10}$ It is an old mistake that was the basic assumption of the 1970 Werner plan, the 1972 "snake," and the present European Monetary System. As for the Delors Report, it believes that "irrevocably fixed exchange rates between national currencies" and "co-ordination of policy between separate national authorities" are necessary (and sufficient?) first steps toward monetary union. Once fixed exchange rates are attained, the report maintains, monetary unification will be completed.

${ }^{9}$ The Single Act elicited the following accolade from Victoria Curzon Price (1988, p. 41): "The Single Market based on the White Paper and the Single Act is a fantastic dream, a pure exercise in deregulation, the devolution of power to the market and economic federalism. It is perhaps one of the best, most market-oriented blueprints for economic cooperation that has ever been devised." By contrast, the Delors scheme would require a centralized network of regulations, even on the decisions of national governments and monetary authorities. It is an interventionist's dream and a liberal's nightmare.

${ }^{10}$ See the Delors Report (1989, p. 10). Strangely enough, this identification is explicitly accepted by The Economist (1989, p. 18): "A fully fixed system would eliminate the bands within which the currencies are allowed to fluctuate. Monetary union would then go one step further by adopting a single currency." 
Despite the experience of the Werner plan, there is still a widely held belief that fixed rates are almost indistinguishable from monetary union and that they are a necessary step toward that goal. This view is unacceptable. In the words of Milton Friedman (1968, pp. 271-72):

The basic fact is that a unified currency and a system of freely floating exchange rates are members of the same species even though superficially they appear very different. Both are free market mechanisms for interregional or international payments. Both permit exchange rates to move freely. Both exclude any administrative or political intermediary in payments between residents of different areas. Either is consistent with free trade between areas, or with a lessening of trade restrictions.

On the other hand, national currencies linked by pegged exchange rates, whether or not through the mechanism of gold, and a system of variable exchange rates, controlled and manipulated by governmental bodies, either through an adjustable peg or day-today market operations, are also members of the same species. Both are interventionist standards. Neither, in my opinion, is consistent with a permanent lessening of barriers to international trade, but only with oscillating barriers as nations shift from surplus to deficit.

Furthermore, although a single European currency automatically implies a single monetary regime and, therefore, is immune to balance-of-payments problems, a system of fixed exchange rates among different national currencies does not. ${ }^{11}$ It can survive if, and only if, it succeeds in imposing coordinated patterns of behavior on all member countries. This last possibility (witness the fate of the Werner plan) is rather remote. ${ }^{12}$

Finally, it is not true that fixed exchange rates would bring Europe closer to monetary unification. In fact, the opposite might happen. ${ }^{13}$ Under fixed exchange rates, domestic policy goals are at times incompatible with external balance. When such a dichotomy arises, the alternative to changing the exchange rate is to impose the burden of the adjustment process on domestic macro-variables. Equilibrium in the balance of payments is then achieved without any change in the exchange rate parity but at the cost of sacrificing domestic stability.

"Friedman has repeatedly argued that the two necessary and almost sufficient conditions for disequilibria in the balance of payments are fixed exchange rates and autonomous national central banks.

${ }^{12}$ See Vaubel (1979, p. 25)

${ }^{13}$ Sir Alan Walters (1988, pp. 505-6) has argued that "compared with a floating system, the EMS entails a considerable politicization of exchange rates.... If the ultimate objective is the monetary integration of Europe through a European Central Bank in a single currency area, then the EMS seems to be hardly a step in the right direction. It creates too many tensions, both economic and political." 


\section{Cato JournaL}

Such a choice is neither desirable nor likely. Should a country be forced to choose between pursuing domestic policy goals or adhering to "irrevocably fixed rates," it would most likely let the exchange rate adjust to a new equilibrium. The arrangement suggested by the Delors Report, therefore, is unlikely to succeed. Needless to say, the failure of the authorities to maintain their "irrevocably fixed rates" for an indefinite period of time would result in frustration and would discredit the idea of monetary unification.

The crucial error of identifying fixed exchange rates with monetary unification is probably the result of a mistaken concept of "gradualism." Gradualism is a very useful political tool, but it can be applied only to problems that have a divisible solution. A common European currency is indivisible: We either have it or we do not, but we cannot have just a bit of it. ${ }^{14}$ It has been possible to liberalize trade gradually, because tariffs are divisible and can be reduced progressively, but I do not see how a common currency can be divided into separate allotments to be incrementally added to the existing bundle. In any case, fixed exchange rates do not represent the "partial" creation of a common currency.

\section{Would a European Currency Be Part of a Fiscal Constitution?}

Money can be a potent tool for controlling and shaping the economy. Its potency ... is exemplified ... by the extent to which control over money has always been a potent means of exacting taxes from the populace at large, very often without the explicit agreement of the legislature.

-Milton Friedman (1968, p. 174)

A major obstacle in the introduction of a common European currency-one that lends credibility to the view of the governor of the Bank of England that "the establishment of a single currency area in Europe ... remains distant" (Leigh-Pemberton 1989, p. 26)-is that money creation is an important source of revenue for national governments, and we must assume that they are reluctant to give it up. But this would also be one of the main advantages of a common European currency. Some supporters of a united Europe, in fact, saw this as the major reason for having a common currency (Einaudi 1985, pp. 102-3).

${ }^{14}$ This does not imply that its introduction cannot be gradual. See Vaubel (1979, pp. 28-30). 
If Europe had a common currency, this would in and of itself represent a significant change in the existing fiscal constitutions of national governments. Those governments would have to forego the use of inflationary finance, the "inflation tax," and debt monetization to finance public spending. As Luigi Einaudi maintained, it would be a substantial improvement over present fiscal procedures. Of course, it is an open question whether national governments can be persuaded to give up such a source of revenue. This problem is not explicitly discussed in the Delors Report, which does not address the question of whether a constitutional framework is needed, but we are reminded that there must be a "system of binding rules governing the size and the financing of national budget deficits." The unresolved question is: How are national governments going to be persuaded to give up such a source of revenue?

\section{A European Monetary Constitution}

The main costs [of monetary union] arise from the loss of autonomy over domestic monetary policy.

—Robin Leigh-Pemberton (1989, p. 12)

Who would control such a central bank?

-Patrick Minford (1989, p. 28)

The preoccupations with the issue of monetary sovereignty are entirely justified. Money matters and, as Milton Friedman has often repeated, it is too important to be left to central bankers. The reasons that we worry about national central bankers managing a nation's money are even more valid in the context of a single currency for Europe. Monetary mismanagement on a national level can be a disaster; on a European level, it would be a catastrophe of unbearable proportions. ${ }^{15}$ Moreover, the argument that binding rules are "undemocratic" because they prevent "elected officials from responding as best they can to the wishes of the electorate" obviously does not apply to the case of Europe. ${ }^{16}$

The problem arises because, with the end of the gold standard, money has become an instrument of discretionary policy to an extent that had been inconceivable. Discretionary manipulation of monetary aggregates by "independent" central banks can produce procyclical rather than anti-cyclical consequences. Instead of achieving

\footnotetext{
${ }^{15}$ See The Economist (1989, p. 20).

${ }^{16}$ See Leijonhufvud (1987) for a criticism of such an argument.
} 


\section{Cato Jounnal}

a higher degree of stability, monetary policy becomes an autonomous source of instability. ${ }^{17}$ This in no way implies incompetence by monetary authorities. Even the most competent central banker does not possess all the knowledge required to make a discretionary anticyclical monetary policy succeed. Information about the workings of our macroeconomic systems is inadequate, short-term predictions are seldom sufficiently reliable, decisions may be untimely, and lags in the effects of monetary changes are largely unknown in advance. ${ }^{18}$

In any case, the outcome of discretionary monetary policy in terms of increased economic instability-already harmful at the national level-would be disastrous at the European level. It is hardly surprising, therefore, that so many people consider that risk unacceptable and oppose a common currency for Europe altogether.

The need to constrain discretion in the conduct of monetary affairs has long been recognized. From the pioneering paper of Henry C. Simons in 1936-which argued that "an enterprise system cannot function effectively in the face of extreme uncertainty as to the action of monetary authorities" - to modern times, many economists have supported the view that monetary policy should be entrusted to rigidly specified rules rather than to the discretion of "authorities." 19 Public choice theorists, for example, argue that only a constitutional set of rigid rules can prevent the ordinary working of political incentives from resulting in monetary instability. ${ }^{20}$ For them, "the absence of an explicit monetary constitution is unacceptable" (Brennan and Buchanan 1981, p. 65). As Friedman (1968, p. 190), the main proponent of a monetary rule, concluded:

If ... we cannot achieve our objectives by giving wide discretion to independent experts, how else can we establish a monetary system that is stable, free from irresponsible governmental tinkering, and incapable of being used as a source of power to threaten economic and political freedom?

A ... possibility is to try to achieve a government of law instead of men literally by legislating rules for the conduct of monetary policy. The enactment of such rules would enable the public to exercise control over monetary policy through its political authori-

\footnotetext{
${ }^{17}$ In other words, it is not enough to say that empirical evidence does not support the view that stabilization policies have had a stabilizing effect on the economy (Romer 1986). The problem is that empirical evidence suggests that they may have had a destabilizing effect. See Friedman (1984, pp. 33-34).

${ }^{18}$ See Bradley and Jansen (1989, p. 37) and Leijonhufvud (1987, p. 131).

${ }^{19}$ See, for example, (Leijonhufvud 1984).

${ }^{20}$ See Brennan and Buchanan (1981, p. 58) and Dowd (1988, p. 21).
} 
ties, while at the same time preventing monetary policy from being subject to the day-to-day whim of political authorities. ${ }^{21}$

A common European currency would be desirable if its adoption meant an end of discretionary short-term policy. Should European nations agree on some kind of monetary constitution, making discretionary manipulation of monetary aggregates impossible, then a common currency for Europe would greatly increase overall stability both in Europe and throughout the world. One could think of a rule fixing the growth rate of some monetary aggregate to a predetermined level and mandating its continuation for an extended period of time (say, three to five years), ${ }^{22}$

The adoption of a monetary rule would be highly desirable per se if it would eliminate the variability of monetary growth, with its accompanying economic instability and uncertainty. But it would also be the solution for the creation of a common currency for Europe. All the justified worries about the surrender of national monetary sovereignty to a European central bank would lose meaning if money was entrusted to predetermined and agreed upon rigid rules rather than to the whim of policymakers possessing discretionary power. Furthermore, all the advantages of a common currency for Europe could be attained.

The problem is that even among those who believe in rigid monetary rules, there is no general agreement on the specific type of rule to adopt. ${ }^{23}$ This is less important, however, than the decision to have a rule at all. Once the principle of a discretionary manipulation of monetary aggregates by an "independent" European central bank is rejected and a rigid monetary rule is introduced, the specifics of the rule can be progressively improved upon, as experience dictates. The main point to be made about rules is that there is no such thing as the "ideal" rule, because as our knowledge progresses, new devices are created that can replace older arrangements. ${ }^{24}$

\footnotetext{
${ }^{21}$ See also Langfeldt, Scheide, and Trapp (1989, p. 40).

${ }^{22}$ A monetary constitution would also impose fiscal responsibility on national governments, thereby achieving two goals at once. In this case, Jerry Jordan's (1986, p. 741) opinion, according to which a fiscal reform is needed in order to achieve the desired monetary reform, would not apply. The monetary reform would achieve both.

${ }^{23}$ Personally, I agree with Langfeldt, Scheide, and Trapp (1989, p. 40): “An important element in a policy rule is that the central bank uses a monetary aggregate that it can control with sufficient precision. Broader aggregates (M1, M2 or M3) can be influenced through changes in the monetary base, but the link seems to become weaker the broader the measure is. So it appears best to use the monetary base which reflects precisely the actions of the central bank."
}

${ }^{24}$ Friedman (1968, pp. 193-94) explicitly recognized this. 


\section{Cato Journal}

In other words, once the principle of entrusting money creation to a rule is accepted, the choice of the best possible rule will be determined by accumulating experience and analytical progress. ${ }^{25}$ Regardless of the kind of rule adopted, it is essential that the target growth rate of the chosen monetary aggregate is adhered to for several years (to favor stable expectations). The concrete design of a European monetary constitution would also have to consider the problem of enforcement, so that it should contain the principle of accountability of the person(s) in charge. ${ }^{26}$

\section{Conclusion}

A common currency for Europe could provide a good opportunity for introducing the kind of constitutional discipline that monetary economists and public choice theorists have advocated for years. It is hard to tell whether politicians and central bankers will become convinced by this argument, but one thing seems clear: The approach of the Delors Report does not seem likely to bring about a common currency for Europe. Because it does not solve (and does not even address) the problem of the shift of monetary sovereignty, it will lead nowhere. Furthermore, committed as it is to the enforcement of fixed exchange rates among European currencies, that approach is likely to promote political conflict and disagreement rather than the harmonization it attempts to achieve.

If Europe does not get a common currency, then it will not reap its great advantages and monetary policy will continue to be in the hands of "independent" central bankers. Money will remain vulnerable to politicians who may be tempted to use it to purchase consent.

\footnotetext{
${ }^{25}$ In the light of the American experience, Friedman (1984, pp. 48-49) changed his proposal of stating the rule in terms of M1 (Friedman 1968, p. 193) and suggested instead that "the quantity of high-powered money-non-interest-bearing obligations of the U.S. government-be frozen at a fixed amount." This clearly illustrates the need for "trying out" proposed rules in order to ascertain how well they work and formulating alternative proposals when the "experiment" is not as successful as hoped. No matter what rule is chosen, however, it seems to me that it must conform to the principles spelled out by Langfeldt, Sheine, and Trapp (1989, p. 43).

${ }^{26}$ The need for a monetary constitution governing the common European currency would be reduced, but not eliminated, if it were introduced through a competitive process of the kind advocated, for example, by Vaubel (1979) and Minford (1989). If the competitive process would lead to a monopoly in money enjoyed by either the "European" or a national currency, then the need for some kind of monetary constitution would again present itself. The mere possibility of creating an alternative to the dominant currency would not be sufficient to constrain the inflationary tendencies of the monetary monopolist. This is why I still believe that a monetary constitution is needed (though I agree with the parallel currency approach to the introduction of a common European currency).
} 
Monetary stability will exist only if governments consider that condition to be in their own self-interest.

Unless European countries are prepared to give up discretion in the conduct of monetary policy (which means giving up money as an instrument of policy), the only kind of monetary unification that can be achieved is that which will spontaneously arise from the liberalization of markets. As the Delors Report indirectly recognized, "full freedom of capital movements and integrated financial markets" would discipline "incompatible national policies." Stable currencies would be preferred in international transactions, and some kind of competition among national currencies would be established. Countries with a high degree of monetary instability would see their national currency rejected by increasingly competitive markets and would, as a result, be forced to change their policy. Therefore, even if a common currency for Europe is not introduced, Europe might still get some kind of discipline in monetary affairs thanks to the "filter mechanism" inadvertently introduced by the Single Act. ${ }^{27}$

\section{References}

Bradley, Michael D., and Jansen, Dennis W. "Understanding Nominal GNP Targeting." The Federal Reserve Bank of St. Louis Review 71 (November/ December 1989): 31-40.

Brennan, H. Geoffrey, and Buchanan, James M. Monopoly in Money and Inflation. Hobart Paper 88. London: Institute of Economic Affairs, 1981.

Buchanan, James M. "Monetary Research, Monetary Rules, and Monetary Regimes." Cato Journal 3 (Spring 1983): 143-46. Reprinted as "Constitutional Strategy and the Monetary Regime." In The Search for Stable Money: Essays on Monetary Reform. Edited by James A. Dorn and Anna J. Schwartz. Chicago: University of Chicago Press, 1987.

Curzon Price, Victoria. 1992: Europe's Last Chance? From Common Market to Single Market. Occasional Paper 81. London: Institute of Economic Affairs, 1988.

Curzon Price, Victoria. "Three Models of European Integration." In Whose Europe? Competing Visions for 1992. London: Institute of Economic Affairs, 1989.

Delors Report. "Report on Economic and Monetary Union in the European Community." Committee for the Study of Economic and Monetary Union.

${ }^{27}$ As Victoria Curzon Price (1989, p. 37) has pointed out:

Creating a single European currency would represent such a loss of sovereignty that were we to get there, we would not be far off full political integration. And yet, if EMS governments stick to their stated commitments . . . they will have tied their hands as firmly as if they had actually created a European central bank.... Even if they retain the right to vary their exchange rates within the EMS, the need to compete for their citizens' savings will force them to behave with extreme fiscal and monetary caution. 


\section{Cato Journal}

Mimeograph. Commission of the European Communities, Brussels, 12 April 1989.

Dowd, Kevin. Private Money: The Path to Monetary Stability. Hobart Paper 112. London: Institute of Economic Affairs, 1988.

Einaudi, Luigi. I problemi economici della Federazione Europea. Lugano, 1944. Reprinted in Europa Padrie Figli, Gli antesignani italiani dell'europeismo. Roma: Editrice Europea, 1985.

The Economist. "European Monetary Union." 24 June 1989.

Fratianni, Michele. "The European Monetary System: How Well Has It Worked? Cato Journal 8 (Fall 1988): 477-501.

Friedman, Milton. "Should There Be an Independent Monetary Authority?" In In Search of a Monetary Constitution. Edited by Leland B. Yeager. Cambridge: Harvard University Press, 1962. Reprinted in Dollars and Deficits: Inflation, Monetary Policy, and the Balance of Payments. Englewood Cliffs, N.J.: Prentice-Hall, 1968.

Friedman, Milton. "The Political Economy of International Monetary Arrangements." In Dollars and Deficits: Inflation, Monetary Policy, and the Balance of Payments. Englewood Cliffs, N.J.: Prentice-Hall, 1968.

Friedman, Milton. "Monetary Policy for the 1980s." In To Promote Prosperity: U.S. Domestic Policy in the Mid-1980s. Edited by John H. Moore. Stanford, Calif.: Hoover Institution, 1984.

Hayek, Friedrich A. Denationalisation of Money. Hobart Paper Special 70, London: Institute of Economic Affairs, 1976.

Jordan, Jerry L. "Monetary Policy as a Fiscal Instrument. Cato Journal 5 (Winter 1986): 733-41.

Langfeldt, Enno; Scheide, Joachim; and Trapp, Peter. "The Case for Money Supply Rules." Geld and Währung/Monetary Affairs 5 (May 1989): 30-47.

Leigh-Pemberton, Robin. The Future of Monetary Arrangements in Europe. Occasional Paper 82. London: Institute of Economic Affairs, 1989.

Leijonhufvud, Axel. "Inflation and Economic Performance." In Money in Crisis. Edited by Barry N. Siegel. Cambridge, Mass.: Ballinger Publishing, 1984.

Leijonhufvud, Axel. "Constitutional Constraints on the Monetary Powers of Government." In The Search for Stable Money: Essays on Monetary Reform. Edited by James A. Dorn and Anna J. Schwartz. Chicago: University of Chicago Press, 1987.

Martino, Antonio. "La politica monetaria e il piano Werner." Rivista di politica economica (May 1971a): 605-12.

Martino, Antonio. 'Il problema monetario internazionale." Nuovi studi politici (May 1971b): 77-81.

Martino, Antonio. "L'unificazione monetaria europea: problemi e prospettive." Quinterni Economici della Cassa di Risparmio di Roma (October 1976): 11-17.

Martino, Antonio. "Verso una moneta europea?" Quinterni Economici della Cassa di Risparmio di Roma (October 1977): 10-17.

Martino, Antonio. "Un nuovo ordine monetario europeo?" Quinterni Economici della Cassa di Risparmio di Roma (July 1978a): 9-14.

Martino, Antonio. "L'unificazione monetaria europea: verso una soluzione intermedia?" Thema, no. 2 (October 1978b): 68-72. 
Martino, Antonio. "La Comunitá Economica Europea, a trent'anni dalla Conferenza di Messina." Economia delle scelte pubbliche anno IV, nn. 1-2 (January-August 1986): 103-7.

Martino, Antonio. "Riflessioni in tema di unificazione monetaria europea." La Comunitá Internazionale 43(2) (Second Quarter 1988): 181-91.

Martino, Antonio. "A Common Currency for Europe or Monetary 'Union'?" In A Citizen's Charter for European Monetary Union. Occasional Paper 5. London: The Bruges Group, December 1989.

Minford, Patrick. "Commentary: The Governor Breaks Euro-Silence." In The Future of Monetary Arrangements in Europe, pp. 27-34. Edited by Robin Leigh-Pemberton. London: Institute of Economic Affairs, 1989.

Romer, Christina D. "Is the Stabilization of the Postwar Economy a Figment of the Data?" American Economic Review 76 (June 1986): 314-34.

Simons, Henry C. "Rules Versus Authorities in Monetary Policy." Journal of Political Economy 44 (1936): 1-30. Reprinted in Readings in Monetary Theory. Edited by F. A. Lutz and L. W. Mints. Homewood, Ill.: R. D. Irwin, 1951.

Vaubel, Roland. Choice in European Monetary Union. Occasional Paper 55. London: Institute of Economic Affairs, 1979.

Vaubel, Roland. "Currency Competition versus Governmental Money Monopolies. Cato Journal 5 (Winter 1986): 927-42.

Vaubel, Roland. "A Public-Choice Interpretation of the Delors Report." Paper presented at the Conference on the Political Economy of International Economic Organizations. Claremont, November 1989.

Walters, Alan. "A Critical View of the EMS." Cato Journal 8 (Fall 1988): 503-6. 


\section{ApProaches to Monetary CONTROL Gordon Pepper}

The major theme in Antonio Martino's paper is that rigid monetary rules offer a greater chance for long-run price stability than do discretionary monetary regimes. Before discussing this theme, however, I wish to make two preliminary points. The first is a very general one: The historical record of inflation during the last 50 years is a dismal one. With the partial exceptions of Germany and Switzerland, monetary policy has failed in its purpose. Martino makes the very important observation that a European currency union provides an excellent opportunity for reform.

The second point has to do with Martino's observation that balance-of-payments problems would cease to exist within Europe after 'currency reform. This is so, but the payments problems would be replaced with the new problem of depressed areas because resistance to cuts in nominal wages hinders a reduction in real wages. Mobility of labor and capital will be essential, but it must be recognized that friction exists even in a country like the United States. The friction is likely to be magnified in the European Community by the differences in language and culture, and prosperous and depressed areas are bound to occur. The point is that in a country like the United States one result of the progressive system of federal direct taxation is that much more revenue is collected from prosperous than from depressed areas. Direct taxation is a form of massive regional aid. If the bureaucrats in Brussels are to be prevented from administering such large handouts in Europe, monetary union may have to be accompanied by a unified system of direct taxation. The point is less important for indirect taxation because a less progressive tax is involved.

Cato Journal, Vol. 10, No. 2 (Fall 1990). Copyright (C) Cato Institute. All rights reserved.

The author is Director of the Midland Montagu Centre for Research in Financial Markets at the City University Business School in London. 


\section{Cato Journal}

\section{The Use of Monetary Targets}

Turning to the main theme of Martino's paper-that is, monetary control by rigid monetary rules-the author contends that the decision to have a target for the money supply is much more important than the choice of the aggregate on which to focus. This is correct in principle, but it may not be so in practice. Fluctuations in the behavior of one aggregate relative to another may seem insignificant from an historical perspective, but they may be of vital importance at the time when officials have to make decisions about whether or not to alter interest rates (assuming that the central bank is not operating on the quantity of bank reserves).

Experience in the 1980s in both the United States and the United Kingdom has illustrated very clearly the danger of focusing on the wrong aggregate. Particular aggregates have been heavily influenced by financial deregulation and innovation. Shifts in inflationary expectations, leading to changes in investors' preference for nominal assets compared with real assets, have been another important influence. In the United Kingdom, serious disruption would have occurred to the real economy in 1980-81 if the authorities had continued to focus on broad money rather than switch to narrow money. Disruption would have also occurred if United States authorities had continued to focus on $\mathrm{Ml}$ in 1982.

The argument so far has been in terms of narrow or broad money, not in terms of the monetary base. The base is unique because the central bank is the only source of ultimate liquidity. Because there are no substitutes, it is by far the safest single aggregate on which to rely. United States experience, however, has illustrated the way in which even the base can become distorted if there are mandatory reserve ratios. The growth of NOW accounts, for example, altered required reserves and affected the base. The conclusion from the behavior of the Anglo-Saxon economies during the 1980s is that the only single aggregate that is safe to target is the monetary base and, further, that there should not be mandatory reserve requirements. In other words, the only rigid target should be for the growth of central bank's own balance sheet.

\section{Transition to a Common Currency}

On a rather different note, there are many general arguments for advocating a gradual move toward a common currency rather than an abrupt change. But there are ways to do it and ways not to do it. Martino reiterates the very important point, made by Milton Friedman as early as 1962 and as recently as last December in the Financial 
Times, that fixed exchange rates are not an intermediate stage between floating exchange rates and a common currency, as many people suppose. Floating exchange rates and a common currency are members of the same family; fixed rates belong to a very different family.

Competing currencies-mentioned at the end of Martino's paper-is the process of evolution that has been advocated by the British Treasury in particular. There are grounds, however, for being concerned about the interaction of this with monetary targets, particularly about what will happen while one currency is competing against another. The objective is for good money to drive out bad. It is important that the suppliers of bad currencies should have an incentive to produce better money, so that the average moves continually toward the best. The danger is that a good currency can win because of the destruction of a bad currency by hyperinflation.

The particular concern is not so much about the fortunes of bad currencies as it is about what happens to good ones. It is about the appropriate code of conduct of the central bank of the good currency during the period in which it is gaining market share. How can any target for the money supply, including one for base money, be set until the gain in market share is known? The problem currently confronting the Bundesbank over German unified currency illustrates the point. If there were to be a currency conversion overnight, the central bank would know the size of its balance sheet and the money stock at the start of the next day's business. If we are given a target for the growth of national income, appropriate monetary rules could then be formulated. But if the period of change from one currency to another were to last several years, how can targets for the money supply be formulated during this period?

An alternative might be for the central bank to assess the stance of monetary policy during the transitional period by the level of interest rates in real terms. If we leave aside the argument about whether this can be done in normal circumstances, the current German experience again illustrates the exceptional difficulties that occur during a transitional period. Inflationary expectations have definitely risen in West Germany, but by how much? Because the rise cannot be measured, the current level of interest rates in real terms is difficult to assess.

Another possibility would be for the central bank to focus on the exchange rate during the period of transition, possibly to act as if it were a currency board linked to an external currency or adopt a commodity standard for a short time. The German experience again illustrates the problem. Capital formation in East Germany needs to rise massively, and it must be matched by an increase in savings. 


\section{Cato JOURnaL}

The obvious savings to divert are the ones that are currently flowing abroad. The surplus on West Germany's current account of its balance of payments, therefore, should fall. To achieve this, the Deutsche mark needs to rise in real terms. Pegging the exchange rate would hinder such an adjustment. Some may argue that the solution can be left to competition between central banks, that successful strategies will evolve as a result of experience. This is correct in the longer run, but it would be a high risk strategy in the shorter run, especially if no one is able to enforce appropriate codes of conduct. $^{1}$

The conclusion is that the problems of transition would be reduced if there were an overnight currency conversion. The policy recommendation, therefore, is complete conversion of currencies on a certain day, followed by the European central bank controlling its own balance sheet.

This conclusion is contrary to that offered by Manuel H. Johnson (1990), who argued that the behavior of bond prices, the foreign exchange rate, and commodity prices might be a better guide to the stance of monetary policy than the behavior of the monetary aggregates. Because I have spent some 20 years in the gilt-edged market (the United Kingdom's government bond market), some comment might be appropriate.

\section{Financial Market Prices as Guides to Monetary Policy}

Johnson argued that financial market prices are summaries of, or aggregates of, information embodying the knowledge and expectations of large numbers of buyers and sellers. These expectations, however, do include ones about the actions of the central bank, which can be most important or even dominant. The result of his suggestion could easily be that a central bank judges that it need not act whenever the market is convinced that it will act! Second guessing is surely not a sound basis for judging the stance of monetary policy.

A more fundamental point is that expectations are only one factor influencing financial markets. They can be influenced by real or financial factors. Examples of the former are growth of dividends, earnings, and profits for stock markets, changes in inflation and real interest rates for bond markets, and the behavior of current accounts of balance of payment and purchasing power parities for foreign exchange markets. Examples of financial forces are the supply of 
money, liquidity, and credit in relation to output and the supply of savings relative to the demand for finance in the economy as a whole. One of the main reasons for establishing the Midland Montagu Centre for Financial Markets at City University Business School was to investigate the importance of financial forces relative to real factors. The conclusion of the research to date is that financial forces can be extremely important. Furthermore, causality can run from financial forces, via the behavior of financial markets, to expectations rather than in the reverse direction.

Assuming that this is correct, there can be times when bond prices are rising merely because there are surplus funds to be invested. The bond market can rise for a while because of surplus growth of money, with sentiment bullish because bond prices are rising, there being an interval before people focus on the inflationary implications of the excess money. At such times, monetary policy is easy and not tight. If a central bank judges the stance of its monetary policy by the behavior of bond prices, then there are occasions on which it could badly misjudge the situation.

In conclusion, I believe that monetary policy is better judged by examining the behavior of the monetary base than by looking at the behavior of bond prices. The policy recommendation remains that the central bank should control the growth of its own balance sheet.

\section{References}

Hayek, Friedrich A. The Denationalisation of Money, 2d ed. Hobart Paper Special 70. London: Institute of Economic Affairs, 1978.

Johnson, Manuel H. "Monetary Policy in an Integrated World Economy." Cato Journal 10 (Fall 1990): 307-314. 